\title{
Growth in the brown shrimp Crangon crangon. I. Effects of food, temperature, size, gender, moulting, and cohort
}

\author{
Marc Hufnagl*, Axel Temming \\ Institute for Hydrobiology and Fishery Science, Olbersweg 24, 22767 Hamburg, Germany
}

\begin{abstract}
Laboratory experiments were performed to determine the growth rates of Crangon crangon as a function of total length $(L=20$ to $60 \mathrm{~mm})$ and temperature $\left(T=5,10,15,20\right.$ and $\left.25^{\circ} \mathrm{C}\right)$ under ad libitum feeding conditions. Mean $( \pm \mathrm{SD})$ growth rates ranged from $0.04 \pm 0.03$ to $0.56 \pm$ $0.1 \mathrm{~mm} \mathrm{~d}^{-1}$ at 5 and $25^{\circ} \mathrm{C}$, respectively. Unexpectedly, the catch date also influenced growth rates, indicating that recently recruited animals grew faster than overwintering shrimps of the same size. Female shrimps of the recent recruitment wave showed significantly higher growth rates than male shrimps. Individual moult intervals were determined using a marking method. Mean intervals $( \pm \mathrm{SD})$ varied between $8 \pm 3.6$ and $45 \pm 7.6 \mathrm{~d}$ for $30 \mathrm{~mm}$ shrimps at 25 and $5^{\circ} \mathrm{C}$, respectively. Temperature and length affected the moult interval but not the moult increment. Variability in the observed growth rates at a given length and temperature was mainly an effect of variable moult increments. Results from 2 pre-experiments also indicate an effect of food quality on growth, with shrimps growing faster when feeding on live copepods in comparison to several other food sources.
\end{abstract}

KEY WORDS: Laboratory growth rates - Moult frequency - Moult interval · Moult increments · Maximum growth

Resale or republication not permitted without written consent of the publisher

\section{INTRODUCTION}

The brown shrimp Crangon crangon (Crustacea, Decapoda) is common along the coastline of Europe (Ehrenbaum 1890, Pihl \& Rosenberg 1984, Henderson \& Holmes 1987, Oh et al. 1999). Brown shrimp support a large fishery in the southern North Sea with landings of up to 37000 tons in 2005 valued between 50 and 100 million Euros (Revill \& Holst 2004, ICES 2010). Despite the ecological and economic importance of brown shrimp, controversial views still exist even about its basic life cycle. In particular, the annual peak of adult shrimps $>50 \mathrm{~mm}$ in total length $(L)$ in autumn (Maes et al. 1998, Henderson et al. 2006) is believed to originate either from the summer eggs of the same year (Boddeke 1982) or from the winter eggs of the previous winter (Kuipers \& Dapper 1984). This substantial uncertainty is mainly related to difficulties with the quantification of brown shrimp growth. Reported growth rates are highly variable even under controlled laboratory and field conditions; results for 20 to $30 \mathrm{~mm}$ shrimps at $20^{\circ} \mathrm{C}$ vary from nearly $0 \mathrm{~mm} \mathrm{~d}^{-1}$ (Edwards 1978), to $>0.2 \mathrm{~mm} \mathrm{~d}^{-1}$ (van Lissa 1977), to $0.5 \mathrm{~mm} \mathrm{~d}^{-1}$ (Dalley 1980). The low growth rates in many laboratory studies are clearly incompatible with the life cycle conclusions of Boddeke (1982) or even Kuipers \& Dapper (1984) and have recently led Campos et al. (2009a) to conclude from a modeling study that previous years' summer eggs are the most important source for commercial catches. Cohort tracking was used as an alternative to laboratory experiments (Henderson \& Holmes 1987, del Norte-Campos \& Temming 1998, Amara \& Paul 2003). However, this technique is mainly reliable only for the smallest shrimps, where growth is fast relative to the time interval between successive recruitment waves.

The North Sea brown shrimp population is influenced by high predation and fishing pressure. Using 
the relationship $\mathrm{N}_{t}=\mathrm{N}_{0} \mathrm{e}^{-Z t}$ (where $\mathrm{N}_{0}$ and $\mathrm{N}_{t}=$ number of individuals at times 0 and $t$ yr) Hufnagl et al. (2010a) determined exponential annual mortality rates $(Z)$ of up to $9 \mathrm{yr}^{-1}$, with a long term (1955-2006) median value of $5.3 \mathrm{yr}^{-1}$ for adult shrimps. Rates for juveniles are even higher ( $Z$ up to $22 \mathrm{yr}^{-1}$; Peterson \& Wroblewski 1984, del Norte-Campos \& Temming 1998). Based on these high levels and the size-related mortality differences, it can be expected that mainly fast growing shrimps will contribute to commercial catches and spawning stock biomass. Slow growing individuals will likely suffer from high cumulative mortality (Houde 1987).

This interaction between mortality and growth makes the assumption of a long period between recruitment and attainment of adult size unlikely. Therefore, the objective of our study was to quantify maximum growth rates under ad libitum feeding conditions.

Initially, we tested whether food quality could explain inter- and intra-study growth variability. The hypothesis was that live food is required to obtain maximum growth rates. Since previous work indicated gender-specific growth rates (Meixner 1969, Campos et al. 2009b), maximum growth rates were separately analyzed for both genders. The experiments aimed to disentangle the effects of size (20 to $60 \mathrm{~mm}$ ) and temperature $\left(5\right.$ to $\left.25^{\circ} \mathrm{C}\right)$ and their possible interactions to cover the field conditions in different seasons throughout the juvenile and adult life phases of brown shrimp. Since growth rates in length per unit time are a combination of length increments and moult intervals, the investigation of individually tagged shrimp also allowed testing whether growth variability is more closely related to variability in moult increments or rather variability in the length of moult intervals.

\section{MATERIALS AND METHODS}

Two small-scale pre-experiments (PRE1 and PRE2) were conducted at the Institute for Hydrobiology and Fisheries Science in Hamburg, Germany, prior to the main growth experiments to examine the influence of food type on observed growth rates. First, different groups of shrimps were grown with different diets, and second, one group of shrimps was fed alternating diets, mainly to test the effect of live copepods, which could only be reared in limited amounts. These pre-experiments were designed to decide if the main experiment could be conducted in Hamburg or should be moved to Helgoland where access to live plankton is easy. Within the main experiment, gender-specific growth rates, gender-specific moult rates, and gender-specific moult intervals were determined under 5 different temperature regimes for shrimps of 20 to $60 \mathrm{~mm} \mathrm{~L}$. A marking method was developed and applied to track growth individually within group experiments.

The main growth experiment was split into 2 parts due to the limited availability of juvenile shrimp. The first part began in May 2006, and the second in July, but both ended in August. All surviving shrimps were frozen at $-80^{\circ} \mathrm{C}$ at the end of each experiment and dry weight was determined after freeze-drying. Applying the length-weight relationship determined by Hufnagl et al. (2010b), the condition index (CI) of each shrimp was calculated as CI $=$ dry weight $/\left(1.301 \times 10^{-6}\right.$ $\left.\cdot L^{3.06}\right)$. CIs for May and July shrimps were compared using Student's $t$-test.

Marking method, growth and gender determination. $L$ was measured to the nearest $\mathrm{mm}$ from the scaphocerite to the tip of the uropods using laminated ruled paper. Total length can be converted to carapace length (CL, measured with a caliper) using $\mathrm{CL}=$ $0.2317 \cdot L-0.7486$ (Hufnagl et al. 2010b).

A marking method was applied in several experiments to track individual shrimps so that individual growth rates, moult intervals and moult increments could be observed. Moult interval (intermoult period) refers to the time (d) elapsed between 2 moult events, and moult increment to the difference in length measured after the recent and the previous moult event.

Animals were marked with a small colored plastic plate which was dipped into a drop of superglue and placed on the carapace or the fourth segment with a pair of tweezers. Superglue immediately hardens in contact with water. Preliminary experiments showed no effect on survival or growth. In these pre-experiments, 63 shrimps were observed over 305 moults (reared at $\sim 15^{\circ} \mathrm{C}$ ) and in only 2 cases was the mark placed in such a way that the exuviae could not be shed off and the animal died. Growth rates of an unmarked control group (10 shrimps, results not shown) were comparable to those of marked animals. A similar marking method was applied by Henderson \& Holmes (1987) also without a negative impact. After ecdysis, the exuvia with the mark was released, and the shrimp therefore lost its mark. Thus, it was possible for 2 or more animals in a tank to have no mark. Limiting the group size to 10 animals ( 5 colors, 2 positions) with known gender (determined from the exuviae) allowed individual tracking with a high degree of certainty. The time interval between checks for moults was always $<1 \mathrm{~d}$. The total length of a moulted shrimp was measured after calcification and hardening of the new exoskeleton. After the measurement, a new mark was added. Growth rates of marked shrimps were calculated as moult increment $(\mathrm{mm})$ divided by moult interval (d). For the final analysis, all growth rates determined for each shrimp were pooled and a mean growth rate for that single shrimp was calculated. 
In experiments where animals were not marked (hereafter referred to as unmarked), all individuals of one tank were pre-sorted to one length. At the end of the experiment, all animals were measured again, and individual growth rates were determined as the difference between final and initial lengths after the elapsed time. For example: if 3 shrimps with initial $L$ of $20 \mathrm{~mm}$ reach sizes of 25, 28 and 30 after $30 \mathrm{~d}$, then individual growth rates will be $0.17,0.27$ and $0.34 \mathrm{~mm} \mathrm{~d}^{-1}$, respectively. Individual tracking of moult increments and intervals was not possible with this method. All tanks always contained only marked or only unmarked shrimps.

Gender was determined based on the shape of the endopodite of the first pleopod and the presence or absence of an appendix masculina at the endopodite of the second pleopod (Tiews 1970). Marked animals were sexed based on the exuviae after each moult and at the end of the experiment. Unmarked animals were only sexed at the end of the experiment prior to freezing. Exuviae were collected daily and not returned to the aquaria.

Individual moult intervals and increments were determined from experiments with marked shrimps, while only mean moult intervals per tank were obtained from experiments with unmarked shrimps. Moult intervals (MI) of unmarked shrimps were calculated according to

$$
\mathrm{MI}=\frac{\mathrm{RT} \cdot \mathrm{n}}{\mathrm{n}_{\mathrm{E}}}
$$

where $\mathrm{RT}=$ run time of the experiment in days, $\mathrm{n}=$ mean number of animals and $\mathrm{n}_{\mathrm{E}}=$ number of exuviae counted during the experiment. The mean moult increment for each aquarium with unmarked shrimps was then calculated as the difference between the individual final length and the common initial length divided by the moult interval.

PRE1 - influence of food source on growth performance: In PRE1, 60 marked animals (18 mm L) were held within 6 plastic tanks (10 l) in 6 groups of 10 animals each. Each tank contained a Petri dish with sand (500 to $1000 \mu \mathrm{m}$ ) that was dried at $70^{\circ} \mathrm{C}$ for $24 \mathrm{~h}$. Water was provided from a recirculation system with a total volume of $\sim 40 \mathrm{~m}^{3}$ sea water, and equipped with protein separators and aerated wet filters. Each group was fed a specific food source, either frozen sprat Sprattus sprattus, fresh tissue of cockle Cerastoderma edule, fresh tissue of common periwinkle Littorina littorea, frozen brown shrimp Crangon crangon, pellet food (Dana feed) or brine shrimp nauplii Artemia salina ( $\sim$ d after hatching). Growth rates for each group were determined over $25 \mathrm{~d}$ spanning 2 to 3 moult events. Water temperature was regulated to $14.9 \pm 0.1^{\circ} \mathrm{C}$, salinity was $31.7 \pm 0.05$, and light:dark cycle was 12:12 h. For each shrimp, the mean growth rate over the whole experimental period was determined from the individually determined growth rates. Dead animals were removed from the tanks in all experiments.

PRE2-influence of live copepods on growth performance: In PRE2, 18 marked shrimps (20 mm $L$ ) collected on August 8, 2005 in Büsum, Germany were held in a basin (50 l) containing sand (500 to $1000 \mu \mathrm{m}$ grain size, dried at $70^{\circ} \mathrm{C}$ ). Water was provided from a recirculation system containing $1 \mathrm{~m}^{3}$ filtered sea water. Animals were fed with fresh tissue of cockle Cerastoderma edule and pellet feed (Dana feed) over $35 \mathrm{~d}$ followed by a period of $10 \mathrm{~d}$ when the same shrimps were fed with $~ 5000\left(280\right.$ shrimp $^{-1}$ ) adult copepods Acartia tonsa each day. Copepods were reared from egg to adult size with Rhodomonas baltica over a period of $4 \mathrm{wk}$ in $120 \mathrm{l}$ tanks prior to the rearing experiment. After $10 \mathrm{~d}$ (on Day 45), the diet was switched back to pellets (Dana feed) combined with polychaetes Arenicola marina (purchased from a fishing supply store). Water temperature was regulated via the room temperature to $18.2 \pm 0.3^{\circ} \mathrm{C}$, salinity was $31.6 \pm 0.76$, and light:dark cycle was 12:12 h. Changes in individual growth were tracked over time, and in the different feeding regimes, applying the marking method.

Main growth experiments. These growth experiments were performed at the AWI Biological Institute Helgoland from May 15 to August 14, 2006, as live plankton is routinely collected there every day. Live plankton was regarded as an optimal food source (based on the result of PRE2). During the early period of the experiments, only shrimps $>30 \mathrm{~mm}$ TL, which were most likely originating from the overwintering cohort, were available. In July, small, recently settled shrimps were also present in the catch; therefore, experiments with smaller individuals began in July.

Abbreviations were used to refer to the different temperatures, marking methods and collection dates. These abbreviations include as the first letter either ' $U$ ' (unmarked) or ' $\mathrm{M}$ ' (marked) to describe the growth determination method. The middle part describes the water temperature $\left(5,10,15,20,25^{\circ} \mathrm{C}\right)$ in the experiment. The last part describes the catch date, either May (M) or July (J). Unmarked animals reared at $15^{\circ} \mathrm{C}$ and collected in July are therefore referred to as 'U15ㅇ' J' (see also Table 1).

Sampling sites: Shrimps were collected on May 8 and 9, 2006 in the Weser $\left(58^{\circ} 49^{\prime} \mathrm{N}, 8^{\circ} 10^{\prime} \mathrm{E}\right)$, Elbe $\left(54^{\circ} 02^{\prime} \mathrm{N}, 8^{\circ} 20^{\prime} \mathrm{E}\right)$ and Eider $\left(54^{\circ} 17^{\prime} \mathrm{N}, 8^{\circ} 27^{\prime} \mathrm{E}\right)$ estuaries within 4 and $8 \mathrm{~m}$ depth using a $3 \mathrm{~m}$ beam trawl aboard the RV 'Uthörn' (salinity 20.7; surface water temperature: $14.4^{\circ} \mathrm{C}$; wind: 4 to $5 \mathrm{Bft}$ east). Animals were transported to the institute on board in a flowthrough seawater basin. Fresh sea water was provided from the vessel's sea water pump and excess water was allowed to spill over the edges. 
Additional shrimp, mainly small individuals used for the experiments that started in May, as well as all animals used in the experiments that started in July, were collected with a push net (1.8 $\mathrm{mm}$ mesh size) in the Wadden Sea off Büsum $\left(54^{\circ} 07^{\prime} \mathrm{N}, 8^{\circ} 51^{\prime} \mathrm{E}\right)$ at $\sim 1 \mathrm{~m}$ water depth on May 12 (salinity 21.7; surface water temperature: $15.4^{\circ} \mathrm{C}$; wind: $2 \mathrm{Bft}$ northeast) and July 10 (salinity 26.2, surface water temperature: $19.2^{\circ} \mathrm{C}$; wind: 5 Bft west). Live shrimp were transported from Büsum to Helgoland in clear plastic bags filled to one-third with seawater under a layer of pure oxygen. This transportation method is commonly used for shipping live fish and shrimps (ASEAN 1998, APEC 1999, Calado \& Dinis 2008).

Initial treatment of experimental animals and acclimation phase: To minimize bias in the experiments due to differences in sampling time or location, all animals available at a given time were randomly combined in 4 sand-filled seawater basins measuring $1.50 \times$ $0.50 \times 0.40 \mathrm{~m}(\mathrm{~L} \times \mathrm{W} \times \mathrm{H})$ and kept at $12^{\circ} \mathrm{C}$. Fresh North Sea water was provided at a rate of $\sim 9 \mathrm{l} \mathrm{h}^{-1} \operatorname{tank}^{-1}$.

All shrimps were fed daily with live polychaetes (mainly Nereis diversicolor, N. virens, N. pelagica, and Lanice conchilega), blue mussel Mytilus edulis halves and green algae Ulva lactuca. Polychaetes, blue mussels and green algae were collected at low tide on the northern shore of Helgoland. Polychaetes provide an important source of polyunsaturated fatty acids which prawns (Benzie 1997) and likewise shrimps are unlikely to be able to produce themselves. Following the results of PRE2, live plankton collected at Helgoland Roads on work days (Greve et al. 2004) was also utilized as food. The volume towed daily with 280 and $500 \mu \mathrm{m}$ plankton nets was $\sim 150 \mathrm{~m}^{3}$. As Crangon crangon mainly feed at night (Feller 2006), concentrated plankton was stored in aerated buckets at $10^{\circ} \mathrm{C}$ and equally distributed among all tanks in the evening.

Shrimps were kept under these conditions from the collection date (May 12) to the beginning of the experiments (May 21). Individuals that were not used in the growth experiments remained in the basins and were held under these conditions to replace dead animals in experiments with marked shrimp. In experiments using unmarked shrimps, dead animals were not replaced with fresh ones, because all shrimps needed to be of similar length at the beginning of the experiment to determine growth rates.
Food supply during the growth experiments: All experiments were performed under ad libitum feeding conditions to obtain maximum growth. Food sources described earlier (polychaetes, live plankton, green algae) were also given throughout the main experiments. Blue mussel tissue was not given due to the risk of accumulated algal toxins and adverse effects on water quality at higher temperatures. For each shrimp, 2 polychaetes were added each day. If this was not sufficient to maintain the daily consumption rate and no worm was left the following day, the ratio was increased. If too many worms were present the following day, the ratio was reduced.

Water supply and tank setup: The supply of pumped sea water and the dimensions of the temperature regulation devices were too limited for a flow through setup with constant water temperatures. Therefore, a closed recirculation setup with daily water exchange was chosen. To gain independent samples, examine the 5 different temperature regimes, and allow the simultaneous investigation of $>1000$ shrimps, the whole experimental setup contained 8 separate recirculation systems distributed over 3 available temperature controlled rooms (Table 1). Each recirculation system (350 1 sea water, seawater pump Oceanrunner 1200) consisted of one $180 \mathrm{l}$ water storage tank and 10 aquaria (polypropylene, $\mathrm{L} \times \mathrm{W} \times \mathrm{H}=40 \times 30 \times 20 \mathrm{~cm}$, $17 \mathrm{l}$ when

Table 1. Experimental setup showing abbreviations used for each experiment. In sequence, $\mathrm{M}$ or $\mathrm{U}$ : marked or unmarked shrimps; number ${ }^{\circ}$ : temperature, and M or J: May or July catch date of shrimps. Also shown are the number of the recirculation system and the climate chamber in which they were reared, the mean $( \pm \mathrm{SD})$ temperature in the recirculation system, the size class used in the treatment (includes shrimps of the specified length $\pm 3 \mathrm{~mm}$ ), the number of aquaria in the recirculation system (in relation to all aquaria in the system), and the number of Crangon crangon of the specified size class within the system. Aquaria used for marked shrimps contained 2 or 3 size classes; density can be obtained from the total number of shrimps per recirc. system and aquarium

\begin{tabular}{|c|c|c|c|c|c|c|}
\hline Abbrev. & $\begin{array}{l}\text { Recirc. } \\
\text { system }\end{array}$ & $\begin{array}{l}\text { Climate } \\
\text { chamber }\end{array}$ & $\begin{array}{c}\text { Temperature } \\
\text { in system } \\
\left({ }^{\circ} \mathrm{C}\right)\end{array}$ & $\begin{array}{l}\text { Size } \\
\text { class } \\
(\mathrm{mm})\end{array}$ & $\begin{array}{l}\text { No. of } \\
\text { aquaria }\end{array}$ & $\begin{array}{l}\text { No. per } \\
\text { size class }\end{array}$ \\
\hline $\mathrm{M}^{\circ} \mathrm{M}$ & 1 & 1 & $4.1 \pm 1.2$ & $30,50-60$ & 10 & 100,60 \\
\hline $\mathrm{M} 10^{\circ} \mathrm{M}$ & 2 & 2 & $10.7 \pm 0.8$ & $40,50,60$ & 10 & $100,80,40$ \\
\hline $\mathrm{M} 15^{\circ} \mathrm{M}$ & 3 & & $\begin{array}{l}15.1 \pm 0.5 \\
\text { (heating) }\end{array}$ & 30,50 & 10 & 100,60 \\
\hline $\mathrm{M} 20^{\circ} \mathrm{M}$ & 4 & 3 & $20.8 \pm 0.6$ & $30,40,60$ & 10 & $100,100,25$ \\
\hline $\mathrm{M} 25^{\circ} \mathrm{M}$ & 5 & & $25.1 \pm 0.7$ & 30,40 & 10 & 100,100 \\
\hline $\mathrm{U} 10^{\circ} \mathrm{M}$ & 6 & 2 & $10.4 \pm 0.4$ & 40 & 6 of 8 & 80 \\
\hline $\mathrm{U} 20^{\circ} \mathrm{M}$ & 7 & 3 & $21.0 \pm 0.6$ & 30 & 6 of 10 & 90 \\
\hline $\mathrm{U} 10^{\circ} \mathrm{J}$ & 6 & 2 & $10.4 \pm 0.4$ & 20 & 2 of 8 & 30 \\
\hline $\mathrm{U} 15^{\circ} \mathrm{J}$ & 8 & & $\begin{array}{l}15.1 \pm 0.5 \\
\text { (heating) }\end{array}$ & 20,30 & 4 & 50,50 \\
\hline $\mathrm{U} 20^{\circ} \mathrm{J}$ & 7 & 3 & $21.0 \pm 0.6$ & 20,30 & 4 of 10 & 80,15 \\
\hline $\mathrm{U} 25^{\circ} \mathrm{J}$ & 5 & & $\begin{array}{l}25.1 \pm 0.3 \\
\text { (heating) }\end{array}$ & 20 & 1 of 10 & 20 \\
\hline
\end{tabular}


filled). The water in the storage tank was replaced once daily with temperature conditioned, filtered and UV treated North Sea water. Temperature was, if necessary, regulated by a 300 or $600 \mathrm{~W}$ heating device. The SD of the temperature over the duration of the experiments (daily measurements) was \pm 0.3 to $\pm 0.7^{\circ} \mathrm{C}$ for experiments at temperatures $>5^{\circ} \mathrm{C}$ (Table 1) and $\pm 1.2^{\circ} \mathrm{C}$ in the $5^{\circ} \mathrm{C}$ experiment. Mean salinity (daily measurements) in all experiments was 31.7 \pm 0.6 .

In each of the 8 systems, up to 10 tanks were placed in 2 racks with 5 vertical levels such that the outflow of the upper tank was the inflow of the lower one. Seawater from the storage tank was pumped at $30 \mathrm{l} \mathrm{h}^{-1}$ into the top and the middle tank of each rack. To maximize water exchange in the tanks, the outlet of the upper tank was always placed opposite to the outlet of the tank below it.

Each tank was checked everyday for dead or moulted animals which were then removed. To avoid systematic errors related to the position of the tanks within racks, the order of all tanks in one system was changed daily using a set of random numbers. All tanks contained a $1 \mathrm{~cm}$ layer of sand. Remaining food was removed every second day.

Experimental design: marked shrimps May: Following the initial acclimation phase of $9 \mathrm{~d}$ for the shrimps from Büsum and $12 \mathrm{~d}$ for the shrimps collected aboard the RV 'Uthörn', the animals were taken from the basins, measured, marked and transferred to the recirculation systems.

Shrimps were acclimated to the experimental tanks for another $10 \mathrm{~d}$ at the field temperature of $\sim 11^{\circ} \mathrm{C}$. Then temperature was gradually heated or cooled to the desired experimental temperature over another $10 \mathrm{~d}$. The entire acclimation therefore required $\sim 30 \mathrm{~d}$. After $62 \mathrm{~d}$ on August 11, the experiment was terminated. Marked animals that died during the experiments or were eaten by their conspecifics were replaced by animals from the stock held in the basins under ad libitum feeding conditions. These shrimps were not temperature acclimated; thus, their growth rates were only used in the analysis if they spent $10 \mathrm{~d}$ plus one complete moult cycle in the experimental tank at the treatment temperature. It was not possible to distinguish whether an animal died due to cannibalism or other causes.

For each marked shrimp, the growth rate was determined as the mean of all growth rates observed for that individual shrimp. Growth rates were only included if the shrimps spent the whole moult interval at the experimental temperature.

Experimental design: unmarked shrimps May: To check whether the marking procedure influenced growth, experiments were conducted with unmarked animals of the same sampling date (May). For these control experiments, 2 size-temperature combinations, referred to as $\mathrm{U} 10^{\circ} \mathrm{M}(L 40 \mathrm{~mm})$ and $\mathrm{U} 20^{\circ} \mathrm{M}(L 30$ $\mathrm{mm}$ ) were chosen. These experiments started on June 25, $15 \mathrm{~d}$ after the experiments with the marked shrimps, and the acclimation procedure was modified to obtain large groups of similar sized shrimp at the start of the experiment. Animals were taken from the basins and acclimated over $10 \mathrm{~d}$ to the desired temperature. Acclimated animals were then sorted, and groups of similar $L$ were placed into one tank.

Experimental design: unmarked shrimps July: Experiments with $20 \mathrm{~mm}$ shrimps (U10 ${ }^{\circ} \mathrm{J}, \mathrm{U} 15^{\circ} \mathrm{J}, \mathrm{U} 20^{\circ} \mathrm{J}$ and $\mathrm{U}^{\circ} 5^{\circ} \mathrm{J}$ ) began in July as this size class was not available in May. Marking of small animals was generally possible but the risk of not exactly matching the mark on the segment and therefore hindering the animals' movements was high. These animals were therefore considered too small for marking and were treated as described above for unmarked shrimp. For comparability with the May experiments, $30 \mathrm{~mm}$ shrimps were also examined at 15 and $20^{\circ} \mathrm{C}$. The experiments started on July 20 after a $10 \mathrm{~d}$ acclimation period. This experiment ended after 25 d on August 14.

\section{RESULTS}

\section{Pre-experiments}

Growth rates of shrimp in the PRE1 experiments varied with diet (Fig. 1). Animals fed with frozen sprat in PRE1 showed median growth rates of zero. The diet consisting of periwinkle or cockle increased median growth rates to $0.1 \mathrm{~mm} \mathrm{~d}^{-1}$ and the shrimp, pellet or brine shrimp diet to $0.2 \mathrm{~mm} \mathrm{~d}^{-1}$ (Fig. 1a). The food type significantly influenced growth rates (ANOVA, p < $0.01)$. Mortality did not differ between the treatments. In total, 20 (sprat: 4; cockle: 4 ; periwinkle: 3 ; shrimp: 4 ; pellets: 2; Artemia: 3) of the 60 animals died during PRE1.

Food source in PRE2 elevated growth rates when the whole group of shrimps was fed with live copepods for $10 \mathrm{~d}$ (Fig. 1). In PRE2, a mean ( \pm SD) growth rate of 0.07 $\pm 0.09 \mathrm{~mm} \mathrm{~d}^{-1}$ was observed for all animals in the tank (Fig. 1b) for the pellet and mussel feeding phase. During the $10 \mathrm{~d}$ of live copepod feeding, all animals moulted. Three of the animals did not grow, 3 grew $0.1 \mathrm{~mm} \mathrm{~d}^{-1}, 5$ grew $0.2 \mathrm{~mm} \mathrm{~d}^{-1}$ and 4 grew 0.4 to 0.5 $\mathrm{mm} \mathrm{d}^{-1}$. Within $2 \mathrm{~d}$ after the $10 \mathrm{~d}$ copepod feeding period, 5 shrimps moulted a second time. These shrimps showed growth rates of 0.15 to $0.5 \mathrm{~mm} \mathrm{~d}^{-1}$. Mean growth was $0.21 \pm 0.18 \mathrm{~mm} \mathrm{~d}^{-1}$ during copepod feeding and $0.13 \pm 0.15 \mathrm{~mm} \mathrm{~d}^{-1}$ afterwards, during the pellet and polychaete feeding phase. During PRE2, 7 of the 18 animals died. 


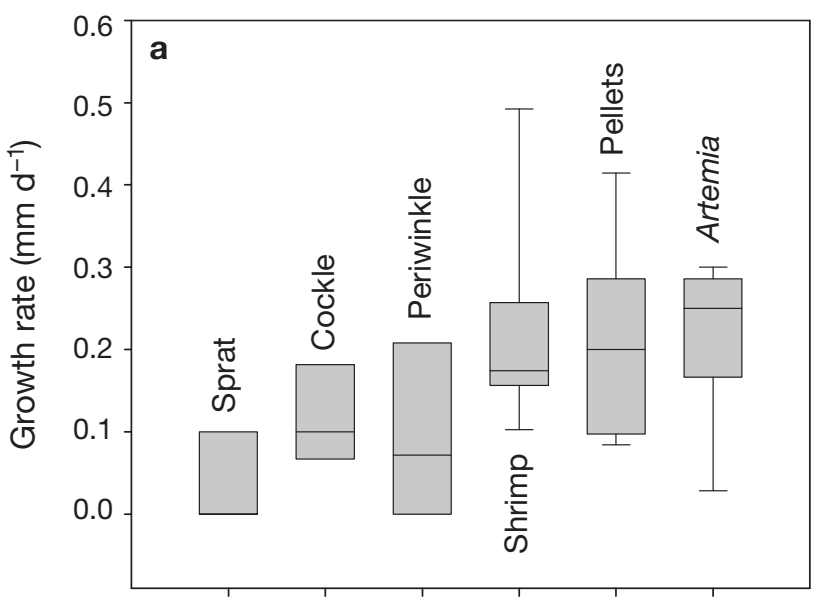

Food source

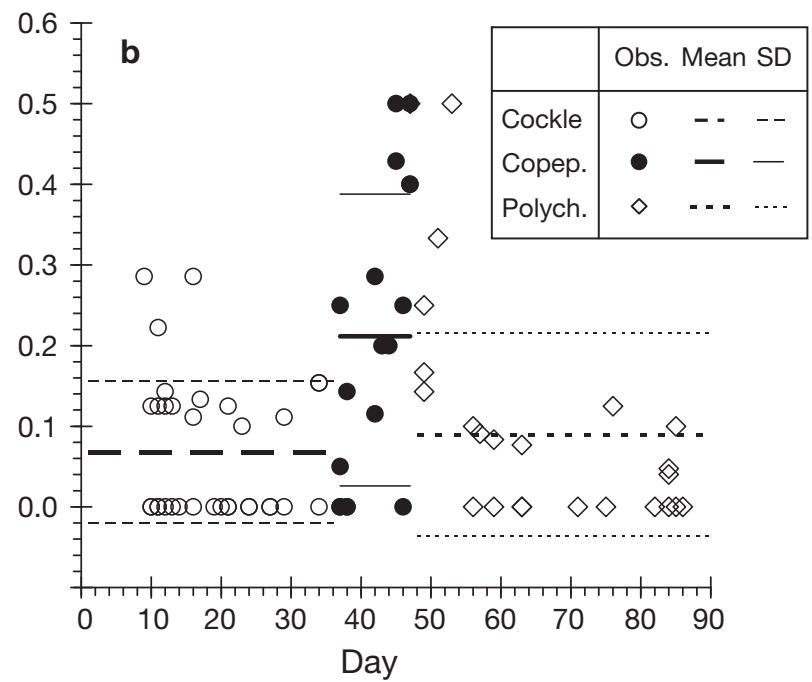

Fig. 1. Crangon crangon. Influence of shrimp diet on observed growth rates. (a) Groups (10 ind. of $18 \mathrm{~mm}$ total length per food source) held at $15^{\circ} \mathrm{C}$. Horizontal line: median, box: 0.25 to 0.75 percentile; whiskers: maximum and minimum values. (b) One group of 18 ind. kept at $18.2^{\circ} \mathrm{C}$ and fed for $35 \mathrm{~d}$ with dry feed and frozen cockles, $10 \mathrm{~d}$ with live copepod Acartia tonsa, and with pellets and polychaetes until Day 90. Each point represents a moult event and the growth rate (= moult increment/moult interval). Thicker horizontal lines: mean; thinner lines: SD of growth rate

\section{Mortality in the growth experiments}

Mortality varied between treatments and was higher for May than for July shrimps. Daily mortality rates (\% $\mathrm{d}^{-1}$ ) in the main growth experiments showed a normal distribution over the whole experimental period (Kolmogorov-Smirnov, p > 0.05) for all tanks. For marked May shrimps, 315 of 1206 ind. survived over $62 \mathrm{~d}$, corresponding to a mean $( \pm \mathrm{SD})$ mortality of $1.7 \pm 1.4 \%$ $\mathrm{d}^{-1}$. For unmarked May shrimps, 47 of 169 ind. sur- vived $>40 \mathrm{~d}$, equaling a mean $( \pm \mathrm{SD})$ mortality of $4.9 \pm$ $5.4 \% \mathrm{~d}^{-1}$. For unmarked July animals, 215 of 241 ind. survived over $25 \mathrm{~d}$ (mean mortality of $0.3 \pm 1.0 \% \mathrm{~d}^{-1}$ ). The SD was high in comparison to the mean as mortality was generally low in this experiment and most mortality rates were 0 . No relationship between mortality and gender (o/ $/ \sigma^{7}$ gender ratio of survivors: 2.97 , gender ratio of dead shrimps: 2.95), position of marking (abdominal seg. 456 dead, carapace 435 dead) or position (pos1 [top] to 5 [bottom]) of the tank in the stack

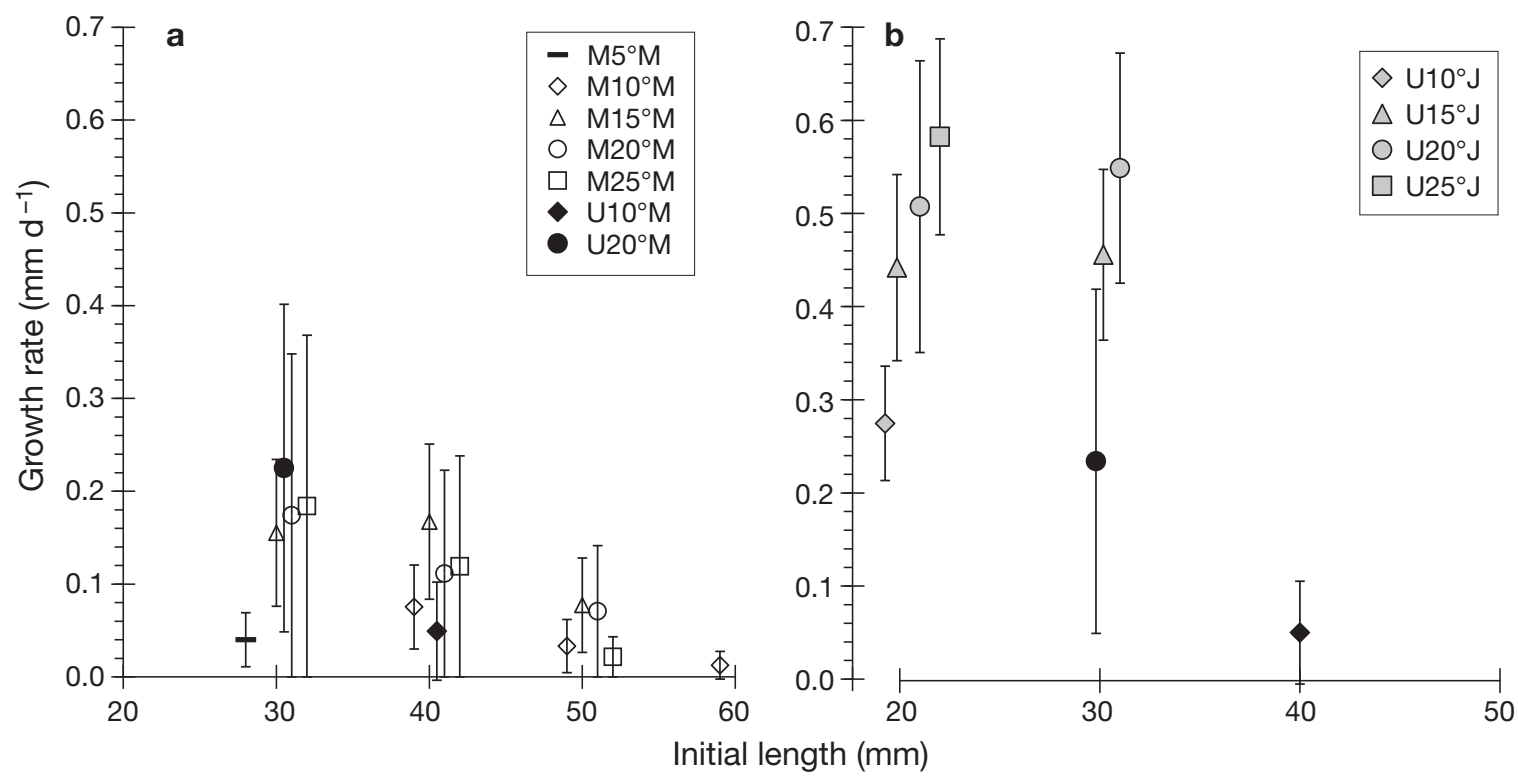

Fig. 2. Crangon crangon. Mean $( \pm \mathrm{SD})$ growth rates $\left(\mathrm{mm} \mathrm{d}^{-1}\right)$ derived from laboratory experiments for (a) all animals collected in May and (b) all unmarked animals collected in May and July. See Table 1 for meanings of abbreviations 
Table 2. Crangon crangon. Mean $( \pm \mathrm{SD})$ growth rates $\left(\mathrm{mm} \mathrm{d}^{-1}\right)$ at different temperatures as observed in the growth experiments

\begin{tabular}{|c|c|c|c|c|c|c|c|c|c|c|c|}
\hline \multirow{2}{*}{$\begin{array}{l}\text { Initial } \\
\text { length (mm) }\end{array}$} & \multirow[b]{2}{*}{$\mathrm{M} 5^{\circ} \mathrm{M}$} & \multirow[b]{2}{*}{$\mathrm{M} 10^{\circ} \mathrm{M}$} & \multicolumn{3}{|c|}{ May marked - } & \multicolumn{2}{|c|}{ May unmarked } & \multirow[b]{2}{*}{$\mathrm{U} 10^{\circ} \mathrm{J}$} & \multicolumn{2}{|c|}{ - July unmarked - } & \multirow[b]{2}{*}{$\mathrm{U} 25^{\circ} \mathrm{J}$} \\
\hline & & & $\mathrm{M} 15^{\circ} \mathrm{M}$ & $\mathrm{M} 20^{\circ} \mathrm{M}$ & $\mathrm{M} 25^{\circ} \mathrm{M}$ & $\mathrm{U} 10^{\circ} \mathrm{M}$ & $\mathrm{U} 20^{\circ} \mathrm{M}$ & & $\mathrm{U} 15^{\circ} \mathrm{J}$ & $\mathrm{U} 20^{\circ} \mathrm{J}$ & \\
\hline 20 & - & - & - & - & - & - & - & $\begin{array}{r}0.27 \\
\pm 0.06\end{array}$ & $\begin{array}{r}0.43 \\
\pm 0.10\end{array}$ & $\begin{array}{r}0.49 \\
\pm 0.15\end{array}$ & $\begin{array}{r}0.56 \\
\pm 0.10\end{array}$ \\
\hline 30 & $\begin{array}{r}0.04 \\
\pm 0.03\end{array}$ & - & $\begin{array}{r}0.16 \\
\pm 0.08\end{array}$ & $\begin{array}{r}0.17 \\
\pm 0.09\end{array}$ & $\begin{array}{r}0.18 \\
\pm 0.09\end{array}$ & - & $\begin{array}{r}0.23 \\
\pm 0.18\end{array}$ & - & $\begin{array}{r}0.44 \\
\pm 0.09\end{array}$ & $\begin{array}{r}0.53 \\
\pm 0.12\end{array}$ & - \\
\hline 40 & - & $\begin{array}{r}0.08 \\
\pm 0.05\end{array}$ & $\begin{array}{r}0.17 \\
\pm 0.08\end{array}$ & $\begin{array}{r}0.11 \\
\pm 0.08\end{array}$ & $\begin{array}{r}0.12 \\
\pm 0.11\end{array}$ & $\begin{array}{r}0.05 \\
\pm 0.05\end{array}$ & - & - & - & - & - \\
\hline 50 & - & $\begin{array}{r}0.03 \\
\pm 0.03\end{array}$ & $\begin{array}{r}0.08 \\
\pm 0.05\end{array}$ & $\begin{array}{r}0.07 \\
\pm 0.04\end{array}$ & $\begin{array}{r}0.02 \\
\pm 0.04\end{array}$ & - & - & - & - & - & - \\
\hline 60 & - & $\begin{array}{r}0.01 \\
\pm 0.01\end{array}$ & $\begin{array}{r}0.04 \\
\pm 0.00\end{array}$ & $\begin{array}{r}0.02 \\
\pm 0.02\end{array}$ & - & - & - & - & - & - & - \\
\hline
\end{tabular}

(pos1: 181 dead; pos2: 162; pos3: 168; pos4: 191; pos5: 190) was observed. Daily mortality rates differed significantly among experiments (ANOVA, Bonferroni post-hoc $\mathrm{p}<0.01$ ).

\section{Growth rates from laboratory experiments}

Crangon crangon growth rates varied with temperature and size (Fig. 2). Mean growth rates were lowest at 5 and $10^{\circ} \mathrm{C}$, with values being $<0.1 \mathrm{~mm} \mathrm{~d}^{-1}$ for all size classes (Fig. 2). At $5^{\circ} \mathrm{C}$, shrimps of 2 size classes $(30,>50 \mathrm{~mm})$ were reared. In the larger group, only 4 animals moulted twice. The remaining large shrimps moulted only once or not at all during $60 \mathrm{~d}$, thus growth rates for the $50 \mathrm{~mm} 5^{\circ} \mathrm{C}$ class were based only on 4 shrimps.

In general, growth decreased with increasing body length. Growth rates of the unmarked animals collected in July were significantly ( $t$-test, $p<0.01$ ) higher than those of shrimps in other experiments (Fig. 2), not only in the $20 \mathrm{~mm}$, but also in the $30 \mathrm{~mm}$ size class, which was available for both sampling months. Besides the higher growth rates, animals collected in July also showed more consistent growth increase with increasing experimental temperatures. Highest mean growth rates $\left(0.56 \mathrm{~mm} \mathrm{~d}^{-1}\right)$ were observed for animals with an initial $L$ of $20 \mathrm{~mm}$ at $25^{\circ} \mathrm{C}\left(\mathrm{U} 25^{\circ} \mathrm{J}\right)$, while lowest growth rates $\left(0.02 \mathrm{~mm} \mathrm{~d}^{-1}\right)$ were noted for the $60 \mathrm{~mm}$ class at $10^{\circ} \mathrm{C}\left(\mathrm{M} 10^{\circ} \mathrm{M}\right.$, Table 2$)$.

Growth rates within each experiment and $L$ class were normally distributed (Kolmogorov-Smirnov test $\mathrm{p}>0.05)$. Growth rates of marked $\left(\mathrm{M} 20^{\circ} \mathrm{M}\right)$ and unmarked $\left(\mathrm{U} 20^{\circ} \mathrm{M}\right)$ shrimps collected in May were not significantly different ( $t$-test, $\mathrm{p}=0.144$ ).

Male and female growth rates within the size and temperature classes were not significantly different $(t-$ test, $\mathrm{p}>0.11$ ) for marked May animals ( $\mathrm{n}$ between 5 and 23). However, unmarked female shrimps from July $\left(\mathrm{U} 15^{\circ} \mathrm{J}\right.$ to $\mathrm{U} 25^{\circ} \mathrm{J}$ ) grew significantly faster than the corresponding males ( $t$-test, $\mathrm{p}<0.01, \mathrm{n}$ between 5 and 37 ; Fig. 3). At $10^{\circ} \mathrm{C}$, not enough animals of the $20 \mathrm{~mm}$ size class reached a length where gender could be accurately determined; therefore, no gender-specific growth rates were determined for this size class.

Mean $( \pm$ SD) dry weight CI was $1.23 \pm 0.19$ for July and $1.17 \pm 0.18$ for May shrimps. Results were not significantly different $(t$-test, $\mathrm{p}<0.01)$.
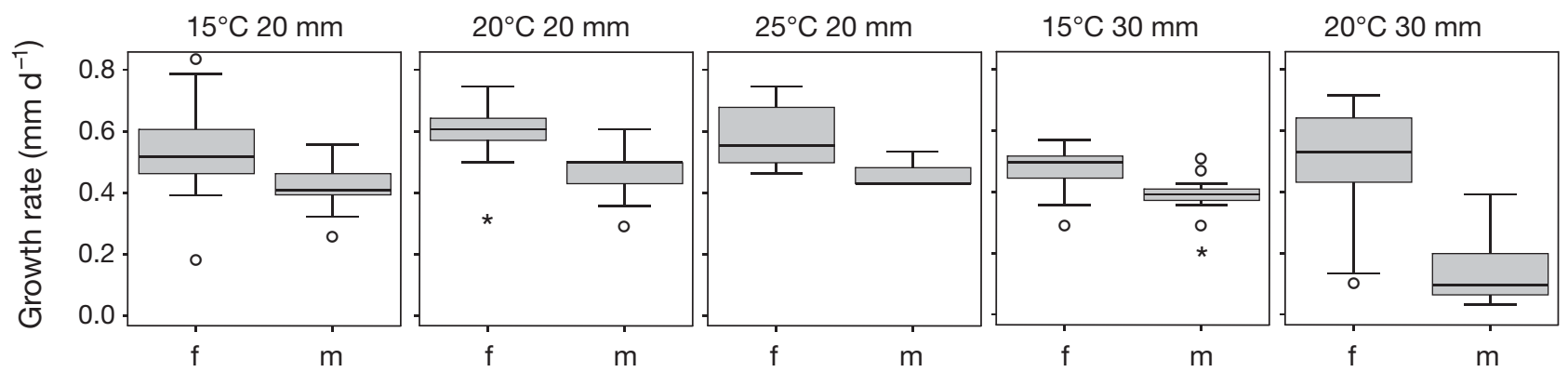

Fig. 3. Crangon crangon. Growth rates $\left(\mathrm{mm} \mathrm{d}^{-1}\right)$ of male $(\mathrm{m})$ and female (f) shrimps derived from laboratory experiments with unmarked animals collected in July. Groups are based on initial length and temperature. Horizontal line: median; box: 0.25 to 0.75 percentile; whiskers: maximum and minimum values; *: outliers, 1.5 to $3 \times$ box length; o: extreme values, $>3 \times$ box length 
Table 3. Crangon crangon. Mean $( \pm \mathrm{SD})$ moult increments $(\mathrm{mm})$ and intervals $(\mathrm{d})$ at different temperatures as observed in the growth experiments

\begin{tabular}{|c|c|c|c|c|c|c|c|c|c|c|}
\hline \multirow{2}{*}{$\begin{array}{l}\text { Initial } \\
\text { length (mm) }\end{array}$} & \multicolumn{5}{|c|}{ Moult increments $(\mathrm{mm})$} & \multicolumn{5}{|c|}{ _ Moult intervals (d) } \\
\hline & $\mathrm{M}^{\circ} \mathrm{M}$ & $\mathrm{M} 10^{\circ} \mathrm{M}$ & $\mathrm{M} 15^{\circ} \mathrm{M}$ & $\mathrm{M} 20^{\circ} \mathrm{M}$ & $\mathrm{M} 25^{\circ} \mathrm{M}$ & $\mathrm{M} 5^{\circ} \mathrm{M}$ & $\mathrm{M} 10^{\circ} \mathrm{M}$ & $\mathrm{M} 15^{\circ} \mathrm{M}$ & $\mathrm{M} 20^{\circ} \mathrm{M}$ & $\mathrm{M} 25^{\circ} \mathrm{M}$ \\
\hline 30 & $\begin{array}{r}1.72 \\
\pm 1.42\end{array}$ & - & $\begin{array}{r}2.59 \\
\pm 1.33\end{array}$ & $\begin{array}{r}1.67 \\
\pm 1.25\end{array}$ & $\begin{array}{c}1.3 \\
\pm \\
\pm 1.19\end{array}$ & $\begin{array}{r}50.2 \\
\pm 11.7\end{array}$ & - & $\begin{array}{r}17.2 \\
\pm 6.2\end{array}$ & $\begin{array}{r}11.7 \\
\pm 1.2\end{array}$ & $\begin{array}{r}8.8 \\
\pm 1.9\end{array}$ \\
\hline 40 & - & $\begin{array}{r}1.97 \\
\pm 1.26\end{array}$ & $\begin{array}{r}1.88 \\
\pm 1.69\end{array}$ & $\begin{array}{r}1.53 \\
\pm 1.09\end{array}$ & $\begin{array}{r}1.23 \\
\pm 1.09\end{array}$ & - & $\begin{array}{r}26.2 \\
\pm 6.0\end{array}$ & $\begin{array}{r}14.1 \\
\pm 4.1\end{array}$ & $\begin{array}{l}15 \\
\pm 3.9\end{array}$ & $\begin{array}{r}11.1 \\
\pm 2.8\end{array}$ \\
\hline 50 & - & $\begin{array}{r}1.09 \\
\pm 1.07\end{array}$ & $\begin{array}{r}1.82 \\
\pm 1.27\end{array}$ & $\begin{array}{r}1.33 \\
\pm 0.94\end{array}$ & $\begin{array}{c}1 \\
\pm 0.94\end{array}$ & - & $\begin{array}{r}37.4 \\
\pm 9.3\end{array}$ & $\begin{array}{l}23.8 \\
\pm 4.7\end{array}$ & $\begin{array}{r}16.7 \\
\pm 3.6\end{array}$ & $\begin{array}{l}13.2 \\
\pm 0.7\end{array}$ \\
\hline 60 & - & $\begin{array}{r}0.67 \\
\pm 0.75\end{array}$ & 1.00 & $\begin{array}{l}0.5 \\
\pm 0.50\end{array}$ & - & - & $\begin{array}{r}44.4 \\
\pm 14.0\end{array}$ & $\begin{array}{l}25 \\
\pm 3.0\end{array}$ & $\begin{array}{l}21 \\
\pm 5.0\end{array}$ & - \\
\hline
\end{tabular}

\section{Moult increments and intervals}

Moult intervals of marked shrimps decreased with increasing temperature and increased with increasing total length (Table 3, Fig. 4). The longest mean $( \pm \mathrm{SD})$ intervals were observed for the $30 \mathrm{~mm}$ size class at $5^{\circ} \mathrm{C}$ $(43 \pm 8 \mathrm{~d})$; shrimps of the $50 \mathrm{~mm}$ size class moulted only once or not at all at $5^{\circ} \mathrm{C}$, therefore no moult intervals could be determined for this size class-temperature combination.

Moult intervals observed for the unmarked May shrimps increased with increasing size and decreasing temperatures (Fig. 4), varying between 9 to 13 and 29 to $34 \mathrm{~d}$ for the $30 \mathrm{~mm} 20^{\circ} \mathrm{C}$ and $40 \mathrm{~mm} 10^{\circ} \mathrm{C}$ experiments, respectively (Fig. 4). Moult intervals of unmarked July shrimps varied between 7 and $19 \mathrm{~d}$ (Fig. 4). No differences in moult intervals between

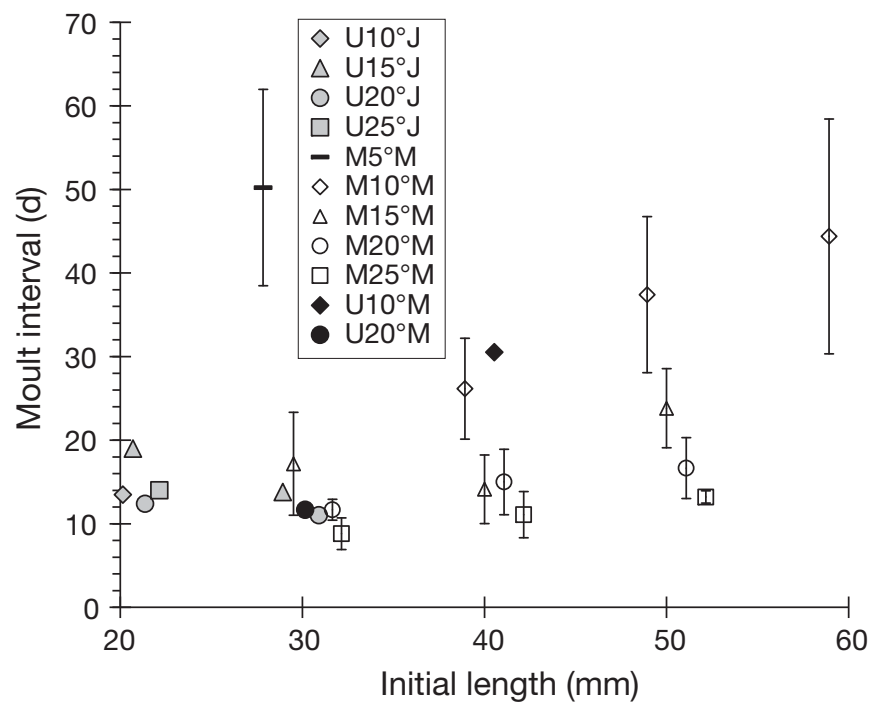

Fig. 4. Crangon crangon. Mean $( \pm \mathrm{SD})$ moult intervals (intermoult period, d) derived from laboratory experiments for all marked and unmarked, May and July animals. See Table 1 for meanings of abbreviations marked males and females in comparable temperature and $L$ classes were detected.

Observed moult increments were highly variable (Table 3, Fig. 5). Mean moult increments of marked May shrimps $\left(\mathrm{M}^{\circ} \mathrm{M}\right.$ to $\left.\mathrm{M} 25^{\circ} \mathrm{M}\right)$ varied between $0.67 \pm$ $0.75 \mathrm{~mm}\left(60 \mathrm{~mm}, 10^{\circ} \mathrm{C}\right)$ and $2.59 \pm 1.33 \mathrm{~mm}(30 \mathrm{~mm}$, $15^{\circ} \mathrm{C}$ ). Individual increments ranged from zero in all size classes and at all temperatures to maximum values of $5 \mathrm{~mm}$ observed at 10 and $15^{\circ} \mathrm{C}$ in the $40 \mathrm{~mm}$ size class. Mean increments of unmarked July animals varied between 3.6 and $7.5 \mathrm{~mm}$. These values refer to the mean interval for all animals in one tank and no standard deviation could be calculated. The largest mean increment (July, $8.2 \mathrm{~mm}$ ) was observed in the $15^{\circ} \mathrm{C}$ experiment, while the lowest of $3.6 \mathrm{~mm}$ for the same $L$ class $(20 \mathrm{~mm})$ was noted at $10^{\circ} \mathrm{C}$. The unmarked May shrimps showed lower increments of 2.3 and $1.5 \mathrm{~mm}$ in the $\mathrm{U} 20^{\circ} \mathrm{M}$ and $\mathrm{U} 10^{\circ} \mathrm{M}$ experiments, respectively. The presence of single moult events with $0 \mathrm{~mm}$ increments or the individual increments (for single moult events) in experiments with unmarked shrimps could not be determined due to the group setup. A statistical comparison of the moult intervals of the 3 experiments (marked May, unmarked May and unmarked July) was also not possible for the same reasons.

In experiments with marked shrimps, correlations between growth rates $\left(\mathrm{mm} \mathrm{d}^{-1}\right)$ and moult increments were higher than that between growth rates and moult intervals (Fig. 6). Moult increments explained between 70 and $89 \%$ of growth variability, whereas moult interval explained only 0 to $20 \%$ of this variability. In a linear model including temperature $(T)$ and shrimp size $(L), 62 \%$ of the variability in moult intervals (marked May animals) could be explained by these 2 variables, whereas only $8 \%$ of the variability in moult increment was explained.

$$
\begin{gathered}
\text { Moult interval }=23.50+0.32 \cdot L-1.10 \cdot T_{i} \\
\mathrm{r}^{2}=0.621, \mathrm{p}<0.01
\end{gathered}
$$

Moult increment $=3.84-0.026 \cdot L-0.068 \cdot T$;

$$
\mathrm{r}^{2}=0.081, \mathrm{p}<0.01
$$




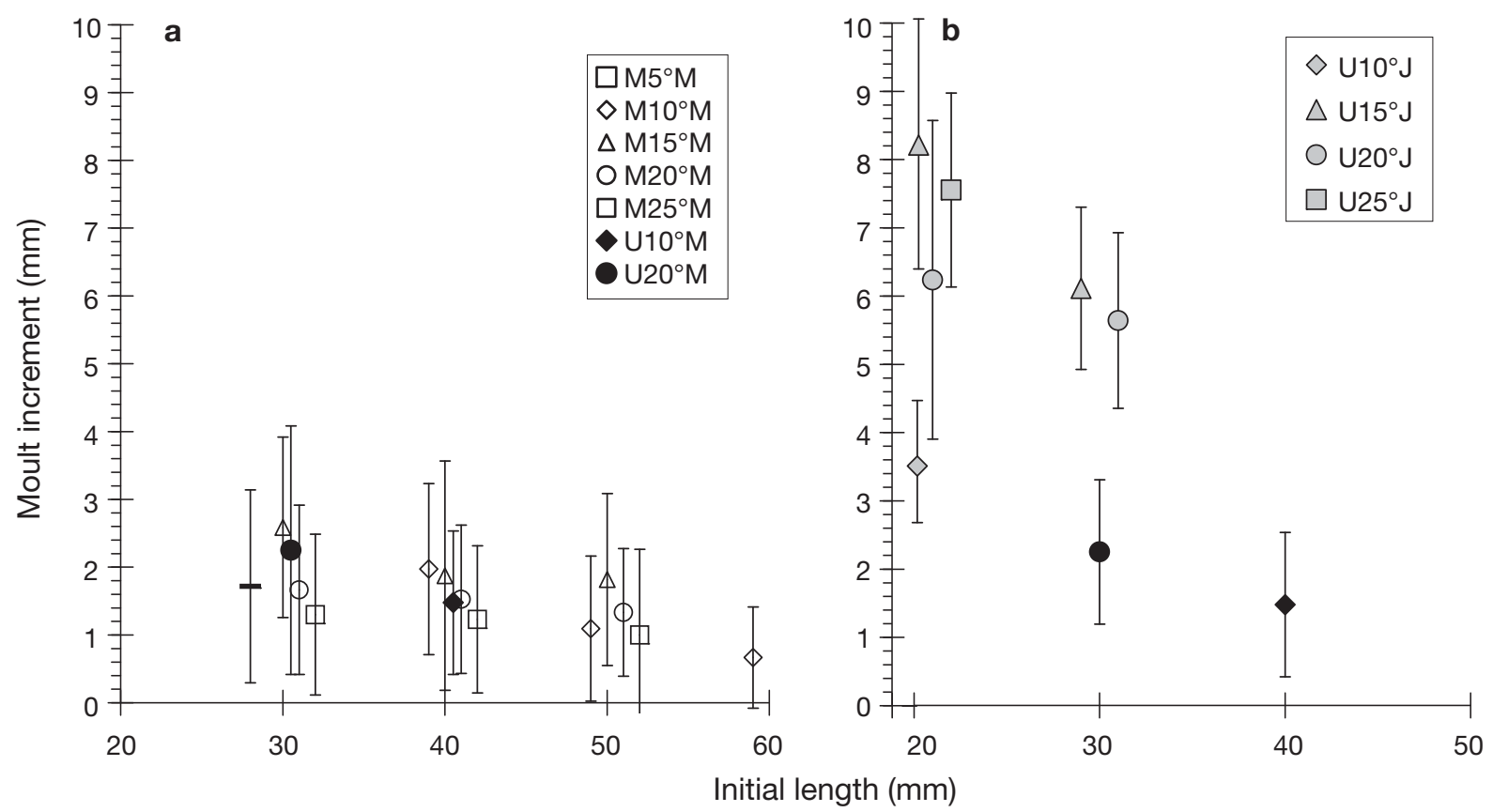

Fig. 5. Crangon crangon. Moult increments (mm) derived from laboratory experiments for (a) all animals collected in May and (b) all unmarked animals collected in May and July. Whisker: 1SD. See Table 1 for meanings of abbreviations

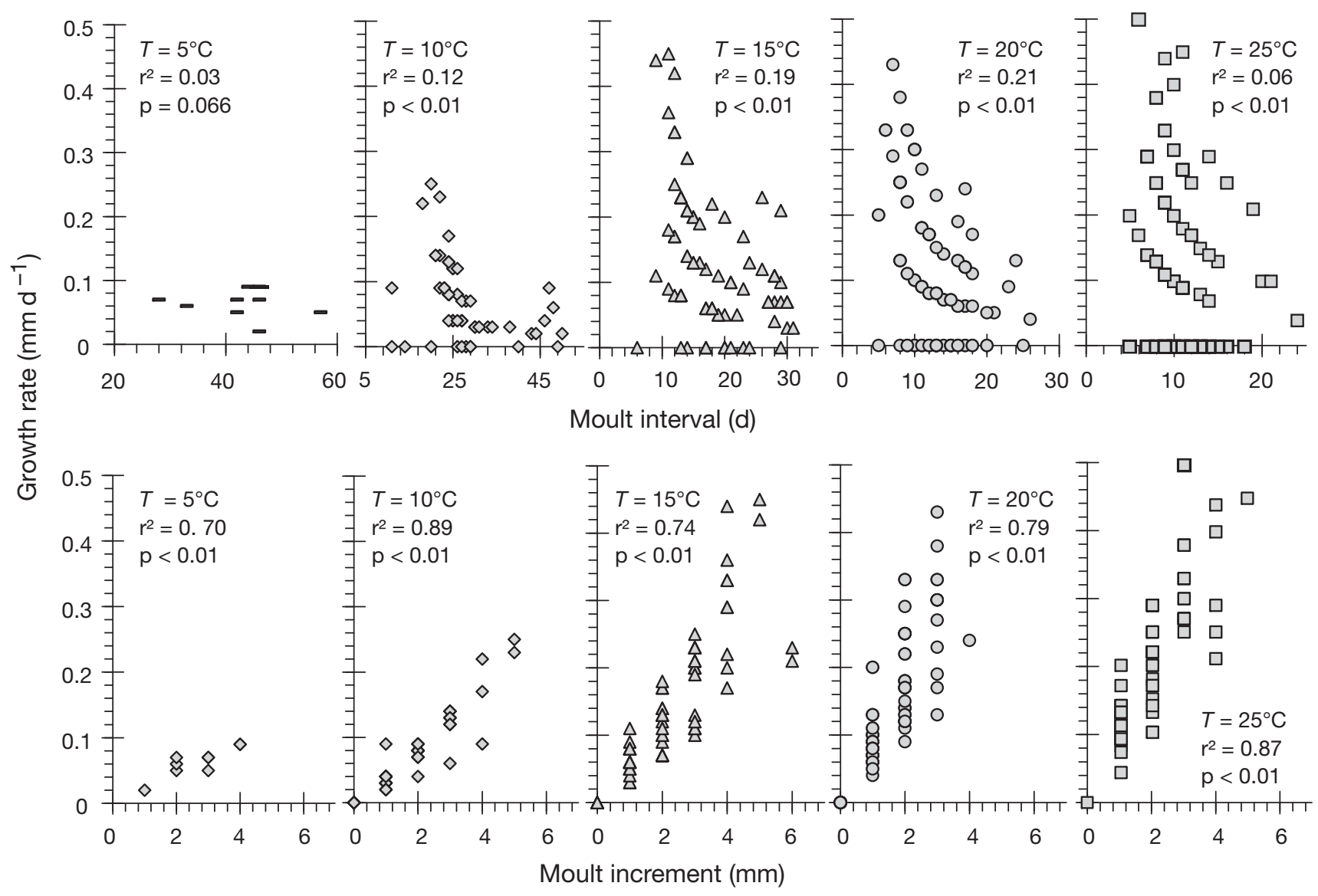

Fig. 6. Crangon crangon. Growth rates $\left(\mathrm{mm} \mathrm{d}^{-1}\right)$ vs. moult increments $(\mathrm{mm})$ and moult interval (d) 


\section{DISCUSSION}

\section{Food type effect on growth rates}

Results of PRE1 and PRE2 showed that food type significantly influenced the growth performance of brown shrimps. Live copepods elevated growth rates by $0.14 \mathrm{~mm} \mathrm{~d}^{-1}$, whereas shrimp on periwinkle, cockle and sprat diets grew very little. The energy contents of the different food types are comparable (Rinke 1938, Daré \& Edwards 1975, Abatzopoulos et al. 1989). The fact that frozen shrimp did not improve growth rate indicates that some components that easily degrade are essential, such as highly unsaturated fatty acids (Benzie 1997, St. John et al. 2001).

Analysis of Crangon crangon stomachs showed that small crustaceans like Corophium sp., Mysis sp., and also pelagic copepods, can make up a major fraction of the diet (Plagmann 1939, Boddeke et al. 1986, del Norte-Campos \& Temming 1994). There are strong indications that $C$. crangon feed off the bottom at night, and also on pelagic zooplankton (del Norte-Campos \& Temming 1998, Feller 2006). In laboratory studies, high growth performance was observed when Artemia nauplii (Dalley 1980: up to $0.53 \mathrm{~mm} \mathrm{~d}^{-1}$; Meixner 1969: up to $0.5 \mathrm{~mm} \mathrm{~d}^{-1}$ ) or live plankton (Uhlig 2002: $16^{\circ} \mathrm{C}$, $20 \mathrm{~mm} L$, up to $0.56 \mathrm{~mm} \mathrm{~d}^{-1}$ ) were provided as food, whereas growth rates were lower when only C. crangon (Edwards 1978: $0.03 \mathrm{~mm} \mathrm{~d}^{-1}$ ), nematodes (Gerlach \& Schrage 1969: $\max .0 .11 \mathrm{~mm} \mathrm{~d}^{-1}$ ) or smelt (Uhlig 2002: $16^{\circ} \mathrm{C}, 20 \mathrm{~mm} \mathrm{~L}, 0.25 \mathrm{~mm} \mathrm{~d}^{-1}$ ) were given. Based on these results, the main growth experiment was planned with live plankton as a mandatory component of the experimental diet.

\section{Cohort effect on growth rates}

In the experiments using shrimps collected in May, only low growth rates were observed and many shrimps showed $0 \mathrm{~mm}$ increments. In contrast, shrimp in the July experiments grew at relatively rapid rates. Moreover, mortality was significantly higher in the May compared to the July experiments. This discrepancy between the 2 groups of experiments can theoretically be explained by several possible factors which can be grouped into (1) experimental artifacts such as marking effects or any differences in water quality, experimental set up, or collection procedure, and (2) biological factors such as age, adaptation or the nutritional history of field collected individuals.

The marking procedure did not significantly influence growth rates when unmarked and marked shrimp were compared in the May experiment. Also, the moult intervals and moult increments were similar for the marked and unmarked, May-collected animals. As growth was also low in the unmarked control groups, impacts due to marking might not be the reason for the observed reduced growth in May shrimps. Henderson \& Holmes (1987) used Loctite adhesive to mark shrimps and also did not observe any negative effects on the shrimps.

There are several other factors that might have caused stress to the animals although most of them might have influenced both marked and unmarked groups similarly. Besides the marking and measuring procedure, stress could have occurred from daily checking procedures (e.g. removing old food and dead animals), or from light or shading effects. However, because fast and slow growing shrimps were reared in similar and partially the same recirculation systems and were generally treated alike, it appears that stress from these conditions was not the growth limiting factor.

In our experiments, all recirculation systems were of comparable design, and May and July shrimps in one treatment ( $25^{\circ} \mathrm{J}$ and $\mathrm{M} 25^{\circ} \mathrm{M}$ ) were actually reared in the same system. Additionally, all experiments overlapped temporally during July and August, and water and food during this overlap period was from the same source. The order of the tanks in the stack was changed randomly, and 3 different climate chambers were used. The experimental setup may therefore be reasonably excluded as a likely cause of the growth differences. For July shrimps, our experimental design actually facilitated growth rates that are comparable to the highest values observed by other authors. At $10^{\circ} \mathrm{C}$, only Beukema (1992) observed higher growth rates than noted here and, at 20 and $25^{\circ} \mathrm{C}$, growth rates observed in our experiment are comparable to those obtained by Meixner (1969), Labat (1977), Dalley (1980) and M. Fonds (pers. comm.).

Differences in catching and handling procedures can also be ruled out as a likely source of growth variability, since comparable size classes in July and May were both collected with a push net at the same location (Büsum), and transported in the same way to Helgoland. Haul duration of beam trawls might increase mortality (Gamito \& Cabral 2003) or lead to damage of shrimps and reduced growth performance due to regeneration (Tiews 1970). However, push net haul duration and transportation were comparable in May and July.

Finally, only the collection date remains as a likely explanation for the growth differences between May and July shrimps. The date determines 2 factors in our experiments: the age and the initial condition of the shrimps. We assumed that shrimps collected in May are $\sim 5$ mo older at the same size than those collected in July. This assumption is based on calculations done by Temming \& Damm (2002) showing that shrimps invad- 
ing the Wadden Sea at a length of $15 \mathrm{~mm}$ in mid June most likely originated from the winter egg production (December to April) and were starting their juvenile life around April or May. Shrimps collected in July were $\sim 20 \mathrm{~mm}$ in size and this size class first occurred in Büsum in June (Hufnagl et al. 2010b). Larger shrimps collected in May therefore likely represent overwintering shrimps originating from the late summer egg production of the previous year (September to October, i.e. 7 to 8 mo old), whereas July shrimps likely represent newly recruited shrimps from the winter egg production ( 2 to 3 mo old). However, it has so far not been demonstrated that mere age differences can explain differences in growth performance of brown shrimps. A possible further explanation might be irreversible non-genetic adaptation as described by Kinne (1962). Once animals have adapted to conditions experienced during early life, in our case winter conditions characterized by low temperatures and low food quality or quantity (Hufnagl et al. 2010b), they might not be able to display high growth once more favourable conditions are established. This possibility cannot be validated here, hence further research is recommended.

As a second factor related to the collection date, the nutritional condition of the animals should be considered. During winter, the animals' energy reserves may become depleted, and this condition might have disproportionally affected the shrimps collected in May. Their mean $( \pm$ SD) dry weight CI was $\sim 15 \%$ lower $(1.63$ $\left.\pm 0.25 \mathrm{mg} \mathrm{mm}^{-3}\right)$ than that of the July cohort $(1.87 \pm$ $0.31 \mathrm{mg} \mathrm{mm}^{-3}$ ). During the experiments, shrimps of the May cohort might have invested less ingested food energy into length growth and more into refilling depleted energy stores. Acclimation, however, was performed under ad libitum feeding conditions, and therefore, should have been long enough to allow the animals to recover. Additionally, the observed differences in dry weight condition between May and July shrimps at the end of the experiments were not significant; thus, condition can also be excluded as a likely explanation for the observed growth differences.

The different growth rates observed between May and July experiments might also reflect seasonal differences in the quality of experimental food. Polychaetes and green algae were provided in all experiments. Feeding on Ulva lactuca was inferred from visible little holes in the leaves and by direct observation of the animals. Feeding on plankton was regularly indicated by increased activity of the shrimps, swimming and catching movements with the chelipeds. The plankton (which was used as one main food) composition and abundance at the Helgoland Reede station, however, varied considerably between weeks (MURSYS, www.bsh.de/de/Meeresdaten/Beobachtungen/ MURSYS-Umweltreportsystem/). Although experi- ments with May and July shrimps overlapped, changes in zooplankton composition (from polychaete larvae to copepods) might have played a role, since copepod concentrations were lower at the beginning of the experiments in May. Nevertheless, an increase in growth performance of marked May shrimps over time was not observed.

\section{Influence of temperature, size and gender}

In general, a positive effect of temperature on growth was observed in our study, which was comparable to the results of other studies (Kuipers \& Dapper 1981, del Norte-Campos \& Temming 1998, Campos et al. 2009b). This positive effect implies that the temperature effect on consumption is stronger than the effect on metabolic cost. Although feeding rates were not determined in the experiments, it can be stated that fewer polychaetes were consumed in the $5^{\circ} \mathrm{C}$ than in the $25^{\circ} \mathrm{C}$ experiment, indicating a temperature effect on consumption.

Besides the positive effect of temperature on absolute length growth rates, a negative trend in growth rate with increasing length was observed in our study as well as in previous studies (Kuipers \& Dapper 1981, del Norte-Campos \& Temming 1998). While May shrimps of $30 \mathrm{~mm} L$ displayed mean growth rates of 0.16 to $0.18 \mathrm{~mm} \mathrm{~d}^{-1}\left(10\right.$ to $20^{\circ} \mathrm{C}$ ), shrimps $>60 \mathrm{~mm}$ at comparable temperatures showed almost no growth $\left(<0.02 \mathrm{~mm} \mathrm{~d}^{-1}\right)$. A decrease in growth rates with increasing length can be explained by differences in the allometric scaling of anabolism (consumption) and catabolism (respiration) according to von Bertalanffy's (1934) growth theory: respiration scales directly with body weight $\left(\sim L^{3}\right)$, whereas food uptake is assumed to be limited by surface (e.g. intestine surface) exchange rates, and is therefore proportional to $L^{2}$.

Growth of female shrimps in our analysis was $~ 30 \%$ higher than that of males. This difference is comparable to those in previous studies on Crangon crangon (Meixner 1969, Labat 1977, Lagardère 1982, Oh et al. 1999, Uhlig 2002) or other shrimp species (Pauly 1982, Campos \& Berkeley 2003, Sainte-Marie et al. 2006). C. crangon follows a pure searching mating system (Boddeke et al. 1991). This implies smaller male sizes in comparison to female size (Correa \& Thiel 2003). However, fecundity is correlated with size in females, which is not true for males (Bauer 2006). Hence, larger females have an advantage, and larger sizes are genetically selected. Large male size is only of advantage for guarding males, such as in Carcinus maenas where males show guarding behaviour and grow larger than female crabs (Behrens Yamada et al. 2005). However, such behavior has not been observed in C. crangon. 


\section{Moult increments and intervals}

Animals collected in May exhibited maximum increments of 5 to $6 \mathrm{~mm}$ and mean increments of 2 to $3 \mathrm{~mm}$. These values are comparable to recently determined mean increments of 2 to $3 \mathrm{~mm}$ by Campos et al. (2009b) and to values observed by Meixner (1969). In contrast, mean increments for July shrimps were 6 to $8 \mathrm{~mm}$ and higher than either those of May shrimps or literature values. Increments of unmarked animals might have been overestimated by unrecognized exuviae that might have been flushed out of the aquarium or consumed by the shrimps. However, as moult intervals of unmarked shrimps were comparable to those of marked animals, it is most likely that the higher growth performance in Crangon crangon was achieved via larger increments. This conclusion can also be drawn from the higher degree of growth variability that was explained by increment than that explained by interval. At all temperatures, with the exception of the $5^{\circ} \mathrm{C}$ treatment, growth rates were more closely correlated with moult increments than with moult intervals. Approximately $70 \%$ of the variability in growth was explained by moult increment but only $20 \%$ was explained by moult interval, mainly due to many moult events with zero increments. Moult intervals were less variable and largely determined by temperature and length of the animals. In starvation experiments, however, only those individuals that were already in the premoult phase at the start of the experiment moulted (Regnault \& Lagardère 1983, Hufnagl et al. 2010b), suggesting that at least the complete lack of food could extend the moult interval. The delay might be explained by the high amount of energy needed for the moulting process. During moulting, respiratory rates increase up to $2.5 \times$ (Hagerman 1970) and ammonia production increase sharply (Regnault 1979). The increased energy demand may partially be due to energy costly tail flipping (Onnen \& Zebe 1982). Additional energy is also needed for the production of the new exuvia, which accounts for $17 \%$ of the whole dry weight of an animal (Regnault \& Luquet 1978). The exuvia has an energy content of $10.5 \mathrm{~kJ} \mathrm{~g}^{-1}$ dry weight (Evans 1984). Gerlach \& Schrage (1969) observed C. crangon eating their exuviae; therefore, a portion of the energy may get recycled. This behavior was not observed during our experiments but cannot be discounted for unmarked July shrimps. However, moult intervals observed in the unmarked treatment are comparable to literature data and intervals observed in the marked treatments. Moult intervals determined by Campos et al. (2009b) range between 20 to $30 \mathrm{~d}$ at $10^{\circ} \mathrm{C}$ and 10 to $15 \mathrm{~d}$ at $25^{\circ} \mathrm{C}$. Evans (1984) observed intermoult periods of 33 to $54 \mathrm{~d}$ at $5^{\circ} \mathrm{C}$ and 9 to $24 \mathrm{~d}$ at $20^{\circ} \mathrm{C}$.

Since moulting also increases vulnerability to preda- tion and cannibalism as has been observed for Crangon crangon (Evans 1984), it is surprising that moulting occurs regularly even if there seems to be no benefit for the individual when the moult increment is zero. One explanation could be that female $C$. crangon can only be fertilized directly after moulting when the exoskeleton is soft (Boddeke et al. 1991); therefore, maturation and reproductive processes may trigger moulting independent of growth rates and recent feeding. Buchholz et al. (2006) suggested that moulting outside the breeding season may be necessary to minimize the level of parasites in Meganyctiphanes norvegica. Although parasites of $C$. crangon have so far only been described for animals from the Mediterranean (Azevedo 2001), other shell diseases like black spots (Dyrynda 1998, Porter et al. 2001, Vogan et al. 2001) or fouling might have led to the evolution of regular moulting that is suppressed only during starvation.

The objective of the present study was to derive a holistic growth model for Crangon crangon that includes the factors length, temperature and gender. However, due to different growth rates observed for May and July shrimps, this was not possible. The question arises as to what mechanisms and reasons were responsible for these differences, and future work should focus on this issue. As we were not able to parameterize a full growth model, another approach might be suitable. Since various data have been published for single size classes or temperatures, a meta-analysis of these data in addition to the data from this study appeared to be a suitable method to fill the existing gaps. In Hufnagl \& Temming (2011 this volume) we therefore combined several growth studies and were able to derive a temperature and length dependent growth model for the brown shrimp. This was used to analyze whether adult shrimps observed in fall originate from juvenile shrimps observed in late spring.

Acknowledgements. We thank J. P. Hermann, F. Buchholz, R. Saborowski, C. Rückert and R. Perger for their support. The study was financially supported by the Federal Ministry of Food, Agriculture and Consumer Protection, Germany, Project No. 03HS030. We also thank the reviewers for their work, helpful comments and suggestions.

\section{LITERATURE CITED}

Abatzopoulos T, Karamanlidis G, Léger P, Sorgeloos P (1989) Further characterization of two Artemia populations from Northern Greece: biometry, hatching characteristics, caloric content and fatty acid profiles. Hydrobiologia 179: 211-222

> Amara R, Paul C (2003) Seasonal patterns in the fish and epibenthic crustaceans community of an intertidal zone with particular reference to the population dynamics of 
plaice and brown shrimp. Estuar Coast Shelf Sci 56: $807-818$

APEC (1999) APEC air shipment of live and fresh fish \& seafood guidelines. APEC \#98-FS-03.1. First Coastal, NY

ASEAN (1998) ASEAN cooperation in food, agriculture and forestry: Asean good shrimp farm management practice. Fish Publ Ser 1:35, Walailak University

Azevedo C (2001) Ultrastructural aspects of a new species, Vavraia mediterranica (Microsporidia, Pleistophoridae), parasite of the French mediterranean shrimp, Crangon crangon (Crustacea, Decapoda). J Invertebr Pathol 78: 194-200

Bauer RT (2006) Same sexual system but variable sociobiology: evolution of protandric simultaneous hermaphroditism in Lysmata shrimps. Integr Comp Biol 46:430-438

Behrens Yamada S, Dumbauld BR, Kalin A, Hunt CE, FiglarBarnes R, Randall A (2005) Growth and persistence of a recent invader Carcinus maenas in estuaries of the northeastern Pacific. Biol Invasions 7:309-321

Benzie JAH (1997) A review of the effect of genetics and environment on the maturation and larval quality of the giant tiger prawn Penaeus monodon. Aquaculture 155:69-85

Beukema JJ (1992) Dynamics of juvenile shrimp Crangon crangon in a tidal-flat nursery of the Wadden Sea after mild and cold winters. Mar Ecol Prog Ser 83:157-165

Boddeke R (1982) The occurrence of winter and summer eggs in the brown shrimp (Crangon crangon) and the pattern of recruitment. Neth J Sea Res 16:151-162

Boddeke R, Driessen G, Doesburg W, Ramaekers G (1986) Food availability and predator presence in a coastal nursery area of the brown shrimp (Crangon crangon). Ophelia 26:77-90

Boddeke R, Bosschieter JR, Goudswaard P (1991) Sex change, mating and sperm transfer in Crangon crangon. In: Bauer RT, Martin JW (eds) Crustacean sexual biology. Columbia University Press, New York, NY, p 164-182

Buchholz CM, Buchholz F, Tarling GA (2006) On the timing of moulting processes in reproductively active Northern krill Meganyctiphanes norvegica. Mar Biol 149:1443-1452

Calado R, Dinis MT (2008) Collection of marine invertebrates for the aquarium trade in European waters: Is anyone surveying? Aquat Conserv 18:335-338

Campos WL, Berkeley SA (2003) Impact of the commercial fishery on the population of bait shrimp (Penaeus spp.) in Biscayne Bay 1986. NOAA Tech Memo NOS NCCOS CCMA 165. University of Miami RSMAS TR 2003-02

Campos J, van der Veer HW, Freitas V, Kooijman SALM (2009a) Contribution of different generations of the brown shrimp Crangon crangon (L.) in the Dutch Wadden Sea to commercial fisheries: a dynamic energy budget approach. J Sea Res 62:106-113

Campos J, Freitas V, Pedrosa C, Guillot R, van der Veer HW (2009b) Latitudinal variation in growth of Crangon crangon (L.): Does counter-gradient growth compensation occur? J Sea Res 62:229-237

Correa C, Thiel M (2003) Mating systems in caridean shrimp (Decapoda: Caridea) and their evolutionary consequences for sexual dimorphism and reproductive biology. Rev Chil Hist Nat 76:187-203

Dalley R (1980) The survival and development of the shrimp Crangon crangon (L.), reared in the laboratory under noncircadian light-dark cycles. J Exp Mar Biol Ecol 47: $101-112$

> Daré PJ, Edwards DB (1975) Seasonal changes in flesh weight and biochemical composition of mussels (Mytilus edulis L.) in the Conway Estuary, North Wales. J Exp Mar Biol Ecol 18:89-97 del Norte-Campos AGC, Temming A (1994) Daily activity, feeding and rations in gobies and brown shrimp in the northern Wadden Sea. Mar Ecol Prog Ser 115:41-53

del Norte-Campos AGC, Temming A (1998) Population dynamics of the brown shrimp Crangon crangon L., in shallow areas of the German Wadden Sea. Fish Manag Ecol 5: 303-322

Dyrynda EA (1998) Shell disease in the common shrimp Crangon crangon: variations within an enclosed estuarine system. Mar Biol 132:445-452

Edwards RRC (1978) Effects of water-soluble oil fractions on metabolism, growth and carbon budget in the shrimp Crangon crangon. Mar Biol 46:259-265

Ehrenbaum E (1890) Zur Naturgeschichte von Crangon vulgaris Fabr. Berlin, Dtsch Seefisch-Verein, Mittl Sekt Küsten- u. Hochseefisch, Sonderbeilage:9-124

Evans S (1984) Energy budgets and predation impact of dominant epibenthic carnivores on a shallow soft bottom community at the Swedish west coast. Estuar Coast Shelf Sci 18:651-672

Feller RJ (2006) Weak meiofaunal trophic linkages in Crangon crangon and Carcinus maenas. J Exp Mar Biol Ecol 330:274-283

Gamito R, Cabral H (2003) Mortality of brown-shrimp discards from the beam trawl fishery in the Tagus estuary, Portugal. Fish Res 63:423-427

Gerlach SA, Schrage M (1969) Freilebende Nematoden als Nahrung der Sandgarnele Crangon crangon. Oecologia 2:362-375

Greve W, Reiners F, Nast J, Hoffmann S (2004) Helgoland Roads meso- and macrozooplankton time-series 1974 to 2004: lessons from 30 years of single spot, high frequency sampling at the only off-shore island of the North Sea. Helgol Mar Res 58:274-288

Hagerman L (1970) The oxygen consumption of Crangon vulgaris (Fabricius) (Crustacea, Natantia) in relation to salinity. Ophelia 7:283-292

Henderson PA, Holmes RHA (1987) On the population biology of the common shrimp Crangon crangon (L.) (Crustacea: Caridea) in the Severn Estuary and Bristol Channel. J Mar Biol Assoc UK 67:825-847

Henderson PA, Seaby RMH, Somes JR (2006) A 25-year study of climatic and density-dependent population regulation of common shrimp Crangon crangon (Crustacea: Caridea) in the Bristol Channel. J Mar Biol Assoc UK 86: $287-298$

Houde ED (1987) Fish early life dynamics and recruitment variability. Am Fish Soc Symp 2:17-29

Hufnagl M, Temming A (2011) Growth in the brown shrimp Crangon crangon. II. Meta-analysis and modelling. Mar Ecol Prog Ser 435:155-172

Hufnagl M, Temming A, Siegel V, Tulp I, Bolle L (2010a) Estimating total mortality and asymptotic length of Crangon crangon between 1955 and 2006. ICES J Mar Sci 67: 875-884

Hufnagl M, Temming A, Dänhardt A, Perger R (2010b) Is Crangon crangon (L. 1758, Decapoda, Caridea) food limited in the Wadden Sea? J Sea Res 64:386-400

ICES (2010) Report of the Working Group on Crangon fisheries and life history. International Council for the Exploration of the Sea, Living Resources Committee, ICES CM 2009/LRC:07

> Kinne O (1962) Irreversible nongenetic adaptation. Comp Biochem Physiol 5:265-281

Kuipers BR, Dapper R (1981) Production of Crangon crangon in the tidal zone of the Dutch Wadden Sea. Neth J Sea Res 15:33-53 
Kuipers BR, Dapper R (1984) Nursery function of Wadden Sea tidal flats for the brown shrimp Crangon crangon. Mar Ecol Prog Ser 17:171-181

Labat JP (1977) Écologie de Crangon crangon (L.) (Decapoda, Caridea) dans un étang de la côte languedocienne. Vie Milieu XXVII:273-292

Lagardère JP (1982) Effects of noise on growth and reproduction of Crangon crangon in rearing tanks. Mar Biol 71: $177-185$

Maes J, Taillieu A, Van Damme PA, Cottenie K, Ollevier F (1998) Seasonal patterns in the fish and crustacean community of a turbid temperate estuary (Zeeschelde Estuary, Belgium). Estuar Coast Shelf Sci 47:143-151

Meixner R (1969) Wachstum, Häutung und Fortpflanzung von Crangon crangon (L.) bei Einzelaufzucht. Ber Dtsch Wiss Komm Meeresforsch 20:93-111

Oh CW, Hartnoll R, Nash RDM (1999) Population dynamics of the common shrimp, Crangon crangon (L.), in Port Erin Bay, Isle of Man, Irish Sea. ICES J Mar Sci 56:718-733

Onnen T, Zebe E (1982) Energy metabolism in the tail muscles of the shrimp Crangon crangon during work and subsequent recovery. Comp Biochem Physiol A 74:833-838

Pauly D (1982) A method to estimate the stock-recruitment relationship of shrimps. Trans Am Fish Soc 111:13-20

Peterson I, Wroblewski JS (1984) Mortality rate of fishes in the pelagic ecosystem. Can J Fish Aquat Sci 41:1117-1120

Pihl L, Rosenberg R (1984) Food selection and consumption of the shrimp Crangon crangon in some shallow marine areas in western Sweden. Mar Ecol Prog Ser 15:159-168

Plagmann J (1939) Ernährungsbiologie der Garnele (Crangon vulgaris Fabr.). Helgol Wiss Meeresunters 2:113-162

Porter L, Butler M, Reeves RH (2001) Normal bacterial flora of the spiny lobster Panulirus argus and its possible role in shell disease. Mar Freshw Res 52:1401-1405

Regnault M (1979) Ammonia excretion of the sand-shrimp Crangon crangon (L.) during the moult cycle. J Comp Physiol 133:199-204

Regnault M, Lagardère JP (1983) Effects of ambient noise on the metabolic level of Crangon crangon (Decapoda, Natantia). Mar Ecol Prog Ser 11:71-78

Regnault M, Luquet P (1978) Variations quantitatives de

Editorial responsibility: Konstantinos Stergiou,

Thessaloniki, Greece l'acide desoxyribonucléique (ADN), au cours de cycle de mue, dans les téguments, le muscle et l'hépatopancréas de la crevette Crangon crangon. J Physiol Paris 74:21-30

> Revill A, Holst R (2004) Reducing discards of North Sea brown shrimp (C. crangon) by trawl modification. Fish Res 68: $113-122$

Rinke H (1938) Über die chemische Zusammensetzung einiger Bodentiere der Nord- und Ostsee und ihre Heizwertbestimmung. Helgol Mar Res 1:112-140

Sainte-Marie B, Bérubé I, Brillo S, Hazel F (2006) Observations on the growth of the sculptured shrimp Sclerocrangon boreas (Decapoda: Caridea). J Crustac Biol 26:55-62

St. John MA, Clemmesen C, Lund T, Köster FW (2001) Diatom production in the marine environment: implications for larval fish growth and condition. ICES J Mar Sci 58: 1106-1113

Temming A, Damm U (2002) Life cycle of Crangon crangon in the North sea: a simulation of the timing of recruitment as a function of the seasonal temperature signal. Fish Oceanogr 11:45-58

Tiews K (1970) Synopsis of biological data on the common shrimp Crangon crangon (Linnaeus, 1758). FAO Fish Rep 4:1167-1223

Uhlig N (2002) Wachstum und Ernährungssituation der Nordseegarnele Crangon crangon (L.). MSc thesis, Institute for Hydrobiology and Fishery Science, University of Hamburg

van Lissa JHL (1977) Aantallen, voedselopname, groei en produktie van de garnaal (Crangon crangon L.) in een getijdengebied, alsmede de voedselopname en groei onder laboratoriumomstandigheden. Interne Verslagen, Nederlands Instituut voor Onderzoek der Zee, Texel 1977 C

Vogan CL, Costa-Ramos C, Rowley AF (2001) A histological study of shell disease syndrome in the edible crab Cancer pagurus. Mar Ecol Prog Ser 47:209-217

von Bertalanffy L (1934) Untersuchungen über die Gesetzlichkeit des Wachstums, I. Teil: Allgemeine Grundlagen der Theorie; Mathematische und Physiologische Gesetzlichkeiten des Wachstums bei Wassertieren. Dev Genes Evol 131:613-651

Submitted: October 11, 2010; Accepted: May 23, 2011

Proofs received from author(s): July 21, 2011 